\title{
Induction of TTF-1 or PAX-8 expression on proliferation and tumorigenicity in thyroid carcinomas
}

\author{
CÉLIA DUPAIN $^{1}$, HAFIZ M. ALI ${ }^{1,2}$, TARIK AIT MOUHOUB ${ }^{1}$, \\ GIORGIA URBINATI $^{1}$ and LILIANE MASSAAD-MASSADE ${ }^{1}$ \\ ${ }^{1}$ Vectorology and Anticancer Therapies, UMR 8203 CNRS, Université Paris-Sud, Gustave Roussy, Université Paris-Saclay, \\ 94805 Villejuif, France; ${ }^{2}$ University College of Veterinary and Animal Sciences, IUB, 63100 Bahawalpur, Pakistan
}

Received May 19, 2016; Accepted July 4, 2016

DOI: $10.3892 /$ ijo.2016.3617

\begin{abstract}
TTF- 1 and $P A X-8$ are responsible for thyroid organogenesis and for maintenance of differentiation in thyrocytes. Thus, we hypothesized that the induction of these two transcription factors could affect proliferation and tumorigenicity. Moreover, the ability of various pharmacological agents to modulate expression of the TTF-1 and $P A X-8$ and their effects on apoptosis were also analysed. For this purpose, cell lines derived from papillary (TPC-1 and BHP 10-3) and anaplastic (ARO) thyroid carcinomas were stably transfected with expression vectors containing $T T F-1$ or $P A X-8$ genes. Subsequently, the effects on expression at gene and protein levels, as well as on cell growth, cell cycle, migration and in vivo tumorigenicity were studied. Our results showed that: i) $T T F-1$ reciprocally induces $P A X-8$ expression; ii) the basal state of $T T F-1$ or $P A X-8$ influences proliferation, migration and tumorigenicity; iii) the induction of $T T F-1$ acts on cell proliferation more than $P A X-8$ and mainly affects tumorigenicity; and iv) $T T F-1$ was found to be more sensitive to epigenetic modulators than $P A X-8$. Therefore, we postulated that both TTF-1 and $P A X-8$ when co-expressed have anti-proliferative and anti-tumorigenic properties up to a threshold expression level and beyond that, are able to induce pro-tumorigenic effects. Hence in future, it will be quite interesting to systematically take into account the basal state of expression of $T T F-1$ and $P A X-8$. It will also be important to study the two thyroid transcription factors as part of a duo. This could open in the long-term, new therapeutic perspectives for thyroid carcinomas.
\end{abstract}

\section{Introduction}

Genes involved in the thyroid differentiation are essentially thyroid transcription factor-1 $(T T F-1)$ and human paired box-8 (PAX-8). Both TTF-1 and PAX-8 control the expression of

Correspondence to: Dr Liliane Massaad-Massade, Vectorology and Anticancer Therapies, UMR 8203 CNRS, Université Paris-Sud, Gustave Roussy, Université Paris-Saclay, 94805 Villejuif, France E-mail: liliane.massade@gustaveroussy.fr

Key words: thyroid transcription factors, thyroid carcinomas, proliferation, apoptosis, tumorigenicity thyroglobulin $(T g)$, thyroperoxidase $(T P O)$, thyroid-stimulating hormone receptor (TSHr) and sodium/iodide symporter (NIS) by binding to the promoters of these genes (1).

$T T F-1$ (also known as NKX2-1, T/EBP or TITF-1) is commonly expressed in thyroid gland and the central nervous system (2). It is considered as a marker of differentiation in thyroid and lung carcinomas and has been widely used to discern the tumours of thyroid and lung origin, in the patients with metastatic disease (3). Moreover, it is also a useful immunohistochemical marker in the diagnosis of these cancers $(4,5)$. TTF- 1 mRNA has been detected in papillary thyroid carcinomas (PTC) but not in anaplastic cancers; therefore, $T T F-1$ would be a marker to distinguish between these two types of thyroid neoplasms $(6,7)$. Regarding its prognosis, $T T F-1$ may be increased in PTC with aggressive clinical course (8). It is also reported that high or low expression of TTF-1 compared to normal levels is a marker of worse prognosis in lung adenocarcinoma; suggesting its importance in disease progression (9). Notably, $N K X 2-1$ encoding $T T F-1$ has been described as a double-edged sword gene due to its dual function, with both pro- and anti-oncogenic activities in lung cancer, depending on the co-existing oncogenic events and differentiation status (10-13).

$P A X-8$ is a transcription factor expressed in thyrocytes and renal cells (14). It was found to be important in the regulation of organogenesis of kidney and Müllerian system and expressed in several tumours including thyroid, kidney and ovarian carcinomas $(14,15)$. It is also considered to be a diagnostic marker for renal, endometrial and ovarian cancers (16) but inconsistent results are reported concerning its expression in thyroid carcinomas. In fact, $P A X-8$ was found to be expressed in differentiated thyroid tumours [PTC and follicular TC (FTC)] while, discrepancies were described in results for anaplastic thyroid carcinomas $(6,17)$. Hence, the relevance of $P A X-8$ in thyroid carcinogenesis still remains to be investigated.

Several authors pointed out the key roles of both $T T F-1$ and $P A X-8$ in the differentiation of thyrocytes. Presta et al (18) postulated that the induction of $P A X-8$ induces re-differentiation of undifferentiated thyroid cancer cells (18). Mu et al (19) showed that co-expression of TTF-1 and $P A X-8$ in thyroid tumour cell lines, derived from papillary or follicular cancers and infected with recombinant adenoviruses (AdTTF-1 and AdPAX-8), leads to accumulation of TPO and $T g$ and organification and intracellular retention of iodine. Interestingly, 
transient expression of $T T F-1$ and $P A X-8$ in mouse embryonic stem cells leads to the development of functional follicular cells able to organize iodine (20). Therefore, $T T F-1$ and $P A X-8$ act together to promote the generation and differentiation of functional thyroid tissue.

Hence, the critical importance of $T T F-1$ and $P A X-8$ in thyroid organogenesis and their function directs the attention to their expression status which could be modulated during tumorigenesis by gene mutations, post-transcriptional regulations or by epigenetic modifications $(21,22)$. The use of histone deacetylase inhibitors [HDACi; trichostatin A (TSA), depsipeptide (DEPSI), sodium butyrate (NaB), suberoylanilide hydroxamic acid (SAHA), LBH589 or valproic acid (VPA)] or demethylating agents [5'azacytidine (5'-AZA), generally used in the treatment of malignant hemopathies] showed dissimilar effects on expression of $T T F-1$ or $P A X-8$ (23-27). We noted only slight discrepancy in the published results, even if the authors used the same cell line and similar molecule, thus, making it quite difficult to conclude about the usefulness of these epigenetic modulators in cell differentiation and anticancer activity. Moreover, Kondo et al (28) correlated the absence of TTF-1 expression with methylated status of $T T F-1$ in several differentiated and undifferentiated thyroid carcinoma cell lines. They also showed a positive correlation between acetylation of histone H3-Lys9 and the absence of $T T F-1$ expression (28) and thus, concluded that DNA demethylating agents could restore $T T F-1$ gene expression in thyroid carcinoma cell lines. Our team showed that other molecules would impact on cell differentiation through expression of $T T F-1$. We reported that $T T F-1$ is tightly regulated through Wnt/ $\beta$-catenin signaling pathway in PTC cells by several mechanisms including transcriptional regulation mediated by $\beta$-catenin-binding to a TCF/LEF-responsive element in the $T T F-1$ promoter and by post-transcriptional modifications influencing TTF-1 mRNA and protein expressions (29). We speculated that the administration of GSK-3 $\beta$ inhibitors such as lithium chloride ( $\mathrm{LiCl}$ ) or other epigenetic $T T F-1$ modulators could stimulate $T T F-1$ expression and as a consequence, promote differentiation of thyroid cells in pathologies where TTF- 1 expression is low or absent (30). This hypothesis was recently validated when $\mathrm{LiCl}$ was shown to improve the efficacy of treatment for thyroid carcinoma by radioiodine (31). Moreover, bortezomib (Velcade ${ }^{\circledR}$ ), a proteasome inhibitor used in multiple myeloma, showed antineoplastic effects on anaplastic thyroid carcinoma-derived cell lines and regulates TTF- 1 and $P A X-8$ expressions (32). Furthermore, it has been described to modulate histone acetylation (33).

Thus, in the present study, we hypothesized that both $T T F-1$ and $P A X-8$ are tightly regulated and their over- or underexpression could influence the tissue differentiation. Therefore, we first investigated the role of $T T F-1$ and $P A X-8$ in proliferation and tumorigenicity, then we analyzed the efficiency of several pharmacological molecules able to modulate $T T F-1$ and $P A X-8$ expressions and studied their outcome in apoptosis.

\section{Materials and methods}

Chemicals. Dulbecco's modified Eagle's medium (DMEM), Opti-MEM, Roswell Park Memorial Institute medium
(RPMI), fetal calf serum (FCS), Lipofectamine $2000^{\mathrm{TM}}$ (1 $\mathrm{mg} / \mathrm{ml})$, propidium iodide (PI) kit and PCR primers were purchased from Life Technologies ${ }^{\mathrm{TM}}$ (Saint Aubin, France). Annexin-V Fluos kit was purchased from Roche (Neuillysur-Seine, France). BD Matrigel ${ }^{\mathrm{TM}}$ (Basement Membrane Matrix Growth Factor Reduced) was purchased from BD Biosciences (Le Pont de Claix, France). Water was purified by Milli-Q system (Millipore, Saint Quentin en Yvelines, France). The chemicals used in the present study were of highest analytical grade.

Cell lines and cell culture. TPC-1, a human PTC cell line and ARO cells derived from anaplastic thyroid carcinoma were kindly provided by Dr C. Dupuy (Gustave Roussy, Villejuif, France). BHP 10-3 $3^{\text {SCmice }}$ cells have the same genetic profile as TPC-1 cell line and were kindly provided by Dr G. Clayman (MD Anderson Cancer Center, Houston, TX, USA). TPC-1 and BHP 10-3 were grown in DMEM and ARO in RPMI medium. DMEM and RPMI were supplemented with $10 \%$ fetal calf serum (FCS), penicillin $(100 \mathrm{U} / \mathrm{ml})$ and streptomycin $(10 \mu \mathrm{g} / \mathrm{ml})$ and maintained at $37^{\circ} \mathrm{C}$ in an atmosphere of $5 \%$ $\mathrm{CO}_{2}$ and $95 \%$ humidity. Cells were systematically tested by PCR analysis to be free of mycoplasma.

Establishment of clones stably expressing TTF-1 and PAX-8. Plasmids used in the present study are human expression vectors (cDNA TTF-1 and cDNA PAX-8) cloned in pcDNA3 $(34,35)$. pcDNA3.1-TTF- 1 and pcDNA3.1-PAX-8 plasmids containing ampicillin and neomycin resistance genes were a generous gift from Dr M. Polak (INSERM UMR S1016 CNRS, UMR 8104 Institut Cochin, Paris, France). The pcDNA3 empty vector was used as a control.

To obtain the cell lines with $T T F-1$ or $P A X-8$ stable expressions, TPC-1, BHP 10-3 and ARO cells were seeded in 6-well plates and transfected with pcDNA-TTF-1 or with pcDNA$P A X-8$ plasmids. In order to control the transfection effects, the three cell lines were also stably transfected with pcDNA3 empty vector. Transfections were realized by Lipofectamine 2000 as recommended by the supplier. Briefly, $6 \mu \mathrm{g}$ of plasmid and $7.5 \mu \mathrm{l}$ of Lipofectamine $2000(1 \mu \mathrm{g} / \mu \mathrm{l})$ were mixed in $2 \mathrm{ml}$ of serum free Opti-MEM culture medium. After $6 \mathrm{~h}$ of incubation at $37^{\circ} \mathrm{C}$, the medium was replaced with complete DMEM culture medium containing FCS. Then, after $48 \mathrm{~h}$ of incubation, cell colonies were collected and expanded in the same growth medium. The selective pressure by neomycin $(88 \mu \mathrm{M})$ was maintained in cell culture during three weeks.

Pharmacological treatments. Cells were seeded in 6-well plates at a concentration of $4 \times 10^{5}$ cells/well in $2 \mathrm{ml}$ of DMEM. After $24 \mathrm{~h}$, cells are treated by one of the pharmacological agents: trichostatin A (TSA; $300 \mathrm{nM}$ or $1 \mu \mathrm{M}$ ), lithium chloride ( $\mathrm{LiCl} ; 20 \mathrm{mM})$, valproic acid (VPA; $3 \mathrm{mM}), 5$ '-azacitidin (5'-AZA; $500 \mathrm{nM}$ or $1 \mu \mathrm{M}$ ) or bortezomib (BOR; $100 \mathrm{nM}$ ). Cells were incubated for $48 \mathrm{~h}$ at $37^{\circ} \mathrm{C}$ in cell culture medium for hydrophilic ( $\mathrm{LiCl}, \mathrm{VPA}$ and $\left.5^{\prime}-\mathrm{AZA}\right)$ or in ethanol $(\mathrm{EtOH}$ $100 \%$ ) for hydrophobic (TSA and BOR) molecules. A calibration curve was performed by spectrophotometry to ensure the final TSA and BOR concentrations after dissolution. Each condition was tested in duplicate in three independent experiments. 
Reverse transcription-quantitative PCR (RT-qPCR). Total RNA extraction and RT-qPCR were performed to compare $T T F-1$ and $P A X-8$ mRNA levels for: i) basal expression of wild-type cell lines; ii) WT cell lines vs. their stably transfected clones; and iii) treated cells with pharmacological molecules vs. untreated cells. RNA extraction was performed from $5 \times 10^{6}$ collected cells using RNeasy Mini kit (Qiagen, Courtaboeuf, France) as previously described (36). RNA purity and quantity were evaluated by NanoDrop ${ }^{\circledR}$ ND-1000 spectrophotometry (spectrophotometer; Thermo Fisher Scientific, Wilmington, DE, USA). First-strand cDNA was generated with M-MLV RT from Life Technologies and realtime PCR (qPCR) was carried out with StepOnePlus PCR System (AB Applied Biosystems, Villebon-sur-Yvette, France) using GoTaq ${ }^{\circledR}$ qPCR Master Mix (Promega, Charbonnièresles-Bains, France) according to the manufacturer's instructions. The following primers were used to amplify the target genes: i) TTF-1 forward (F), 5'-CGCGTTTAGACCAAGGAAC-3' and TTF-1 reverse (R), 5'-GAGTGTGCCCAGAGTGAAG-3'; ii) $P A X-8(\mathrm{~F}), 5^{\prime}$-AGGTGGTGGAGAAGATTGG-3' and PAX-8 (R), 5'-ATAGGGAGGTTGAATGGTTG-3'. Gene expression was determined by quantification-comparative $2^{-\triangle \triangle \mathrm{Ct}}$ method (37) and normalized to GAPDH levels using these sequences: [GAPDH (F), 5'-ATCCCATCACCATCT TCCAG-3' and GAPDH (R), 5'-CCATCACGCCACAGTTT CC-3']. Results are expressed as relative mRNA levels comparing the clones or treated cells to WT cell lines and represent at least three independent experiments realized in duplicate.

Immunoblotting. Cells were lysed and total proteins were extracted using mammalian protein extraction reagent (M-PER; Thermo Fisher Scientific, Rockford, IL, USA) in the presence of a protease inhibitor cocktail (Roche, Neuilly-sur-Seine, France) and quantified by Bio-RAD assay at $570 \mathrm{~nm}(36,38)$. The amount of $30 \mu \mathrm{g}$ of each sample were heated at $70^{\circ} \mathrm{C}$ for $10 \mathrm{~min}$ with $1 \mathrm{X}$ sample reducing buffer (NuPAGE sample reducing agent; Invitrogen) and $1 \mathrm{X}$ sample loading buffer (NuPAGE LDS sample agent; Invitrogen). Samples were then loaded on $10 \%$ polyacrylamide gel (NuPAGE Bis-Tris mini gels 10\%; Life Technologies). Proteins were transferred on nitrocellulose membranes using iBlot ${ }^{\mathrm{TM}}$ Dry blotting system (Invitrogen). After saturation with either I-Block reagent (Tropix, Inc., Bedford, MA, USA) or 10\% BSA (bovine serum albumin) solution, membranes were incubated overnight at $4^{\circ} \mathrm{C}$ under agitation with one of the following primary antibodies: monoclonal rabbit TTF-1 (1:1,000, ab133737; Abcam Biochemicals, Paris, France); monoclonal rabbit PAX-8 (1:1,000, ab53490; Abcam Biochemicals). $\beta$-actin-HRP (horseradish peroxidase) was used as an internal control (1:1,000; SigmaAldrich Chemicals Co., Saint Quentin Fallavier, France). Blots were then washed and incubated with corresponding secondary antibodies: anti-rabbit-AP (alkaline phosphatase 1:20,000; Tropix) or anti-rabbit-HRP (1:3,000; Cell Signaling Technology, Saint Quentin en Yvelines, France). Bands were revealed with CDP-Star Chemiluminescence reagent (alkaline phosphatase system; Perkin Elmer, Courtaboeuf, France) or by enhanced chemiluminescence reagent (HRP system, Clarity ${ }^{\mathrm{TM}}$; Bio-Rad Laboratories,
Marnes-la-Coquette, France). Experiments were repeated at least 3 times.

Doubling time and cell cycle analysis. In order to establish the doubling time of WT cell lines compared to their stably transfected clones by $T T F-1$ or $P A X-8,10^{4}$ cells/well were seeded in $200 \mu \mathrm{l}$ culture medium in 96-well plates. Cells were then incubated in the IncuCyte ${ }^{\mathrm{TM}}$ (Essen Instruments, Inc., Ann Arbor, MI, USA); that allows a non-invasive automated method to monitor viable cell growth and proliferation in culture. Each well was scanned by camera fitted in IncuCyte ${ }^{\mathrm{TM}}$ at 4-h intervals for three days, with 4 images per well. Thereby, time lapse cell confluence was obtained for each cell type and their doubling time was calculated according to an exponential regression equation, given as: $\mathrm{y}=\mathrm{axe}^{\mathrm{bx}}$, via the formula: $\mathrm{t} 1 / 2=\ln (2) / \mathrm{b}$.

For cell cycle analysis, TPC-1, BHP 10-3 and ARO and their corresponding transfected clones were collected and incubated with DNA staining buffer $(50 \mu \mathrm{g} / \mathrm{ml}$ PI in $0.1 \%$ sodium citrate, $0.1 \%$ Triton X-100, $100 \mu \mathrm{g} / \mathrm{ml}$ RNase A) in the dark, for $30 \mathrm{~min}$ at room temperature. Samples were then analysed by flow cytometry (Accuri C6 flow cytometer; BD Biosciences, San Jose, CA, USA). The results are of at least three independent experiments and represent the percentage of cells distributed in the cell cycle phases, in the stable clones vs. their corresponding WT cell lines or in treated cells vs. untreated ones.

Cell migration assays. Scratch test was performed to evaluate the effects of stable transfection either with $T T F-1$ or PAX-8 genes on cell migration, as previously described (39). Briefly, $100 \mu 1 \mathrm{BD}^{\text {Matrigel }}{ }^{\mathrm{TM}}$ was plated in 96-well ImageLock ${ }^{\mathrm{TM}}$ cell migration plates (Essen BioScience Inc., Ann Arbor, MI, USA) $24 \mathrm{~h}$ before seeding of TPC-1, BHP 10-3 and ARO cells and their corresponding stably transfected clones. Cells (1x10 $/$ well) were then plated and when reached $90 \%$ confluence, the monolayer was scratched with a 96-pin WoundMaker (Essen BioScience). The cells were maintained in fresh culture medium until complete wound confluence and the cell mobility was monitored by IncuCyte ${ }^{\mathrm{TM}}$ every $4 \mathrm{~h}$ by 'scratch wound' scan type. Results are presented as scratch wound width in function of time.

Annexin V apoptosis assay. Apoptosis was determined by flow cytometric analysis using Annexin V kit. Each cell line was seeded in 6-well plates $\left(3.5 \times 10^{5}\right.$ cells/well) in $2 \mathrm{ml}$ medium and pharmacologically treated with EtOH $(20 \mu \mathrm{l})$, TSA (300 nM or $1 \mu \mathrm{M}), \mathrm{LiCl}(20 \mathrm{mM})$, VPA (3 mM), BOR $(100 \mathrm{nM})$ or 5'-AZA (500 nM or $1 \mu \mathrm{M})$. After $48 \mathrm{~h}$ of incubation, cells were collected and centrifuged and the pellets were stained with Annexin V Fluos kit (Roche, Neuilly-sur-Seine, France) according to the manufacturer's instructions. Experiments were performed in triplicate of independent experiments and data represent percentage of apoptotic cells compared to nontreated cells, normalized to EtOH condition.

Animal studies and tumorigenicity tests. All animal experiments and the use of cell lines were approved by the institutional Ethics Committee of Animal Experimentation (CEEA) and research council (Integrated Research Cancer 

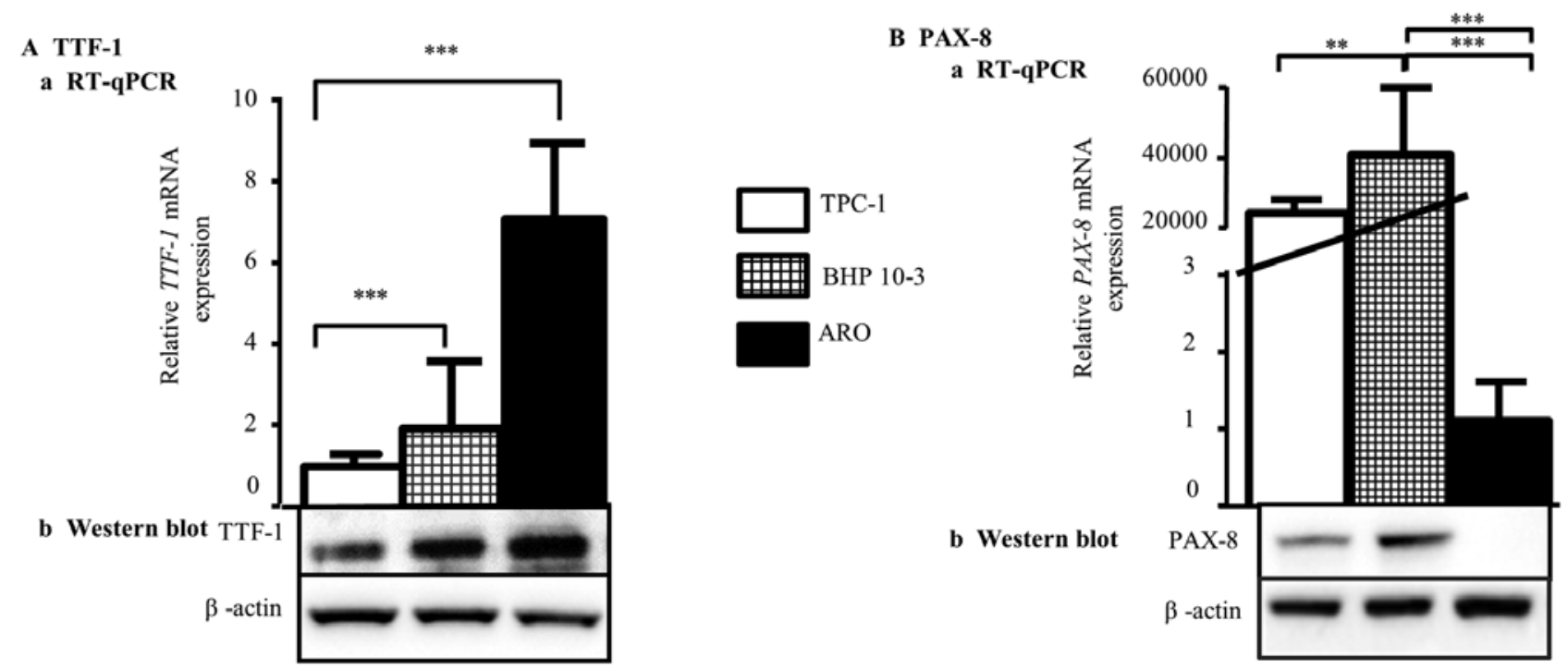

Figure 1. Basal expression of TTF-1 and PAX-8 in TPC-1, BHP 10-3 and ARO. Total mRNA and proteins were extracted from TPC-1, BHP 10-3 and ARO cells. (A-a) Relative TTF-1 mRNA levels were analysed by RT-qPCR and compared to TPC-1 cell line. (B-a) Relative $P A X-8$ mRNA levels were analysed by RT-qPCR and compared to TPC-1 cell line. All the results are normalised to GAPDH mRNA levels and are the mean \pm SD of three independent experiments. ${ }^{* *} \mathrm{P}<0.01,{ }^{* * *} \mathrm{P}<0.001$. Western blot analysis of TTF-1 (A-b) and PAX-8 (B-b) proteins in TPC-1, BHP 10-3 and ARO cell lines. $\beta$-actin was used as an internal control. Results are representative of two independent experiments.

Institute in Villejuif; IRCIV), registered in the French Ministry of Higher Education and Research (Ministère de l'Enseignement Supérieur et de la Recherche; MESR) under the authorization number CEEA IRCIV/IGR no. 26: 94-226, no. 2011-09 and carried out according to French laws under the conditions established by the European Community (Directive 2010/63/UE). Six-week-old nude nu/nu and five-week-old NSG (NOD/SCID Gamma) female mice were purchased from the Animal Facility of the Institute Gustave Roussy and housed in a sterilised laminar flow caging system. Water and bedding were given ad libitum and autoclaved before being put in the cages. All efforts were made to minimize animal sufferance and animals were sacrificed by $\mathrm{CO}_{2}$ inhalation at the end of the experiments, before the collection of tumours.

Nude mice were used to test the tumorigenicity of BHP 10-3 and ARO cell lines and their respective clones. Since, TPC-1 cells are reported as non-tumorigenic in nude mice (40), NSG mice were used for this purpose. All cell lines and their corresponding clones diluted in $100 \mu \mathrm{l}$ PBS were injected subcutaneously into the flank of mice ( $\mathrm{n}=5$ /group) at a rate of $2.0 \times 10^{6}$ cells/mouse for BHP $10-3$ and ARO or $10^{7}$ cells/mouse for TPC-1. Mice were monitored every two or three days for tumour growth and then sacrificed when tumours reached a volume of $1,000 \mathrm{~mm}^{3}$. Tumours were immediately frozen in liquid nitrogen for western blot analysis.

Protein extractions from tumours and western blot experiments. Tumours were ground, total proteins were extracted and western blots were performed as described above, to evaluate expression of the TTF-1 and PAX- 8 protein.

Statistical analysis. The data are presented as mean \pm SD (standard deviation). By using GraphPad Prism 4 software, Mann-Witney test was employed to compare between two groups of treatments and Kruskal-Wallis test was performed to compare among multiple treatments. Non-parametric analysis of longitudinal data in factorial experiments was performed to compare the treatments in vivo, using 'nparLD' package from ' $\mathrm{R}$ ' software. $\mathrm{P}<0.05$ was considered as the statistically significant level.

\section{Results}

TTF-1 and PAX-8have differentexpression profiles in wild-type cell lines. First, we tested expression of the TTF-1 and PAX-8 in TPC-1, BHP 10-3 and ARO cell lines by RT-qPCR (Fig. 1A) and western blot analysis (Fig. 1B). Regarding TTF-1 basal expression, our results showed that TTF-1 is more expressed in ARO compared to TPC-1 and BHP 10-3 cell lines, both at mRNA (Fig. 1A-a) and protein (Fig. 1B-a) levels. Concerning PAX-8, mRNA and protein were found to be highly expressed in BHP 10-3 cells compared to TPC-1 cells whereas it was detected slightly in anaplastic ARO cell line (Fig. 1A-b and $\mathrm{B}-\mathrm{b})$. These results confirmed the thyroid origin of the three cell lines, and the different expression profiles of TTF-1 and $P A X-8$ genes.

TTF-1 upregulates $P A X-8$ in thyroid carcinoma cell lines. TPC-1, BHP 10-3 and ARO cell lines were stably transfected with pcDNA plasmids containing either TTF-1 or PAX-8 genes or with pcDNA3 empty vector. After 3 weeks of neomycin selection, the resulting clones were collected and characterized by RT-qPCR and western blot analysis.

Firstly, we assessed the effects of pcDNA3 empty vector on the expression of $T T F-1$ and $P A X-8$ mRNA by RT-qPCR. We found that $T T F-1$ mRNA level was not affected by pcDNA3 stable transfection in either TPC-1 or ARO cells. Concerning BHP 10-3 cells, we noted a decrease in mRNA TTF- 1 expression that will not interfere with our following experiments, since no induction in TTF- 1 transcription factor was observed. Also, for $P A X-8$, the stable transfection did not affect the mRNA levels of the three cell lines tested (data not shown). 
A TTF-1

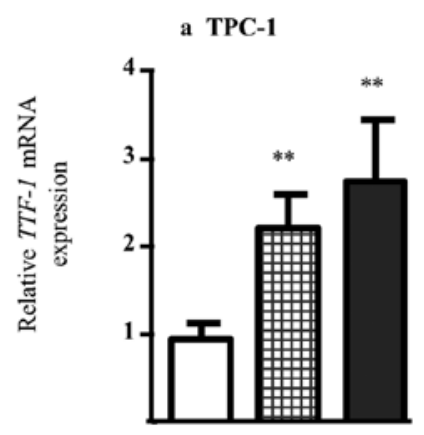

B PAX-8
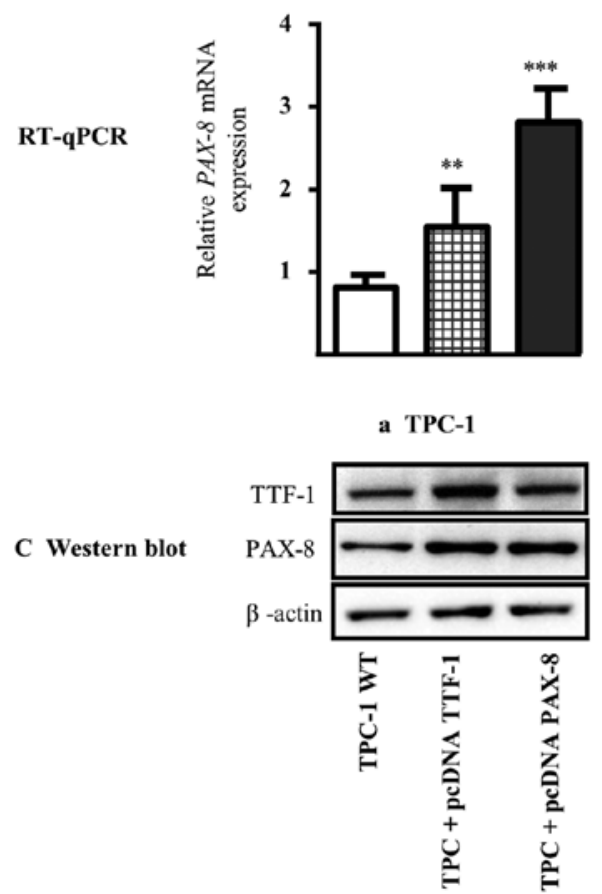

b BHP 10-3

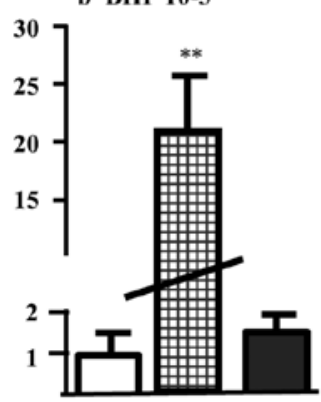

b BHP 10-3

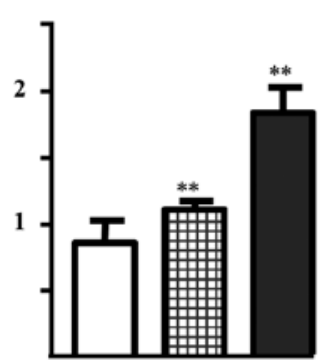

b BHP 10-3

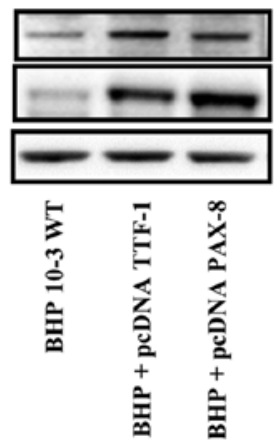

c ARO

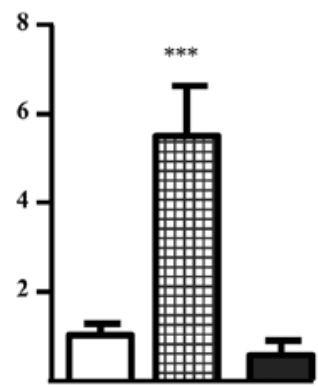

ARO

:
H
:
त.
II

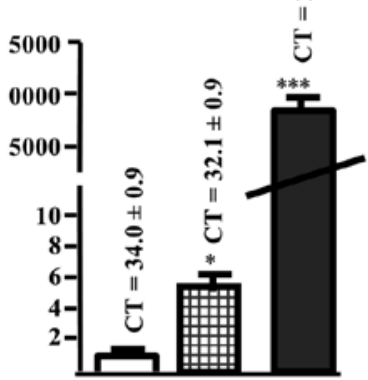

c ARO

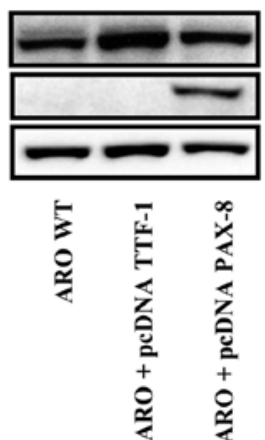

Figure 2. Induction of the expression of TTF-1 and PAX-8 in TPC-1, BHP 10-3 and ARO, after stable transfection. Total mRNA was extracted from TPC-1 (A-a and B-a; RT-qPCR), BHP 10-3 (A-b and B-b; RT-qPCR) and ARO cells (A-c and B-c; RT-qPCR). (A) TTF-1 and (B) PAX-8 mRNA levels were analysed by RT-qPCR and compared to their corresponding wild-type cell lines. Results are normalised to GAPDH mRNA levels. Bars represent mean \pm SD of three independent experiments. ${ }^{*} \mathrm{P}<0.05,{ }^{* *} \mathrm{P}<0.01,{ }^{* * *} \mathrm{P}<0.001$. TTF-1 and PAX-8 protein levels were tested by western blot analysis in TPC-1 (C-a), BHP 10-3 (C-b) and ARO (C-c), clones and their respective WT cell lines. $\beta$-actin was used as an internal control. Results are representative of at least three independent experiments.

Then, clones derived from each cell line transfected with pcDNA plasmids containing either TTF-1 or $P A X-8$ genes were tested for the expression profiles of TTF-1 and PAX-8 mRNA and their corresponding proteins (Fig. 2). The relative mRNA TTF- 1 level in transfected clones with pcDNA TTF-1 for TPC-1, BHP 10-3 and ARO cells was 2.5-, 20- and 5-fold, respectively more important compared to their corresponding wild type cell lines (Fig. 2A-a-c; RT-qPCR). The upregulation of TTF-1 mRNA levels was paralleled by a similar increase in TTF-1 protein in all pcDNA TTF-1 derived clones (Fig. 2C-a-c; western blot analysis, upper panels). Similarly, the relative mRNA $P A X-8$ expression was respectively 3-, 2and 8000-fold higher in TPC-1, BHP 10-3 and ARO clones transfected with pcDNA PAX-8 vector (Fig. 2B-a-c; RT-qPCR) and paralleled with higher PAX-8 protein level (Fig. 2C-a-c; western blot analysis, mid-panels). It should be noticed that the strong increase in $P A X-8$ level found in ARO clone transfected with pcDNA PAX- 8 could be a consequence of low mRNA levels at basal state in ARO WT cells (ct=34 \pm 0.9$)$ (Fig. 2B-c, RT-qPCR and 2C-c, western blot analysis).

Therefore, in the three cell lines tested, TTF-1 induction is able to enhance mRNA and protein PAX- 8 contents except when the basal state of PAX-8 is absent or too low (Fig. 2B-c and $2 \mathrm{C}-\mathrm{c}$ ). Taking together our results showed that the upregulation of TTF-1 is able to induce PAX-8 expression.

Upregulation of TTF-1 acts more effectively on cell doubling time and cell cycle than PAX-8. Both cell doubling time and cell cycle of the clones were compared to their corresponding WT cells. In the three clones stably transfected with pcDNA TTF-1, our results showed that the doubling time calculated according to the confluence was significantly increased compared to their counterpart WT cells (Table I). The pcDNA PAX-8 transfection had no effects on doubling time of TPC-1 
Table I. Doubling time and cell cycle progression of TPC-1, BHP 10-3 and ARO cells and their corresponding clones transfected with pcDNA TTF-1 or pcDNA PAX-8.

\begin{tabular}{|c|c|c|c|c|}
\hline \multirow[b]{2}{*}{ Cell lines and clones } & \multirow{2}{*}{$\frac{\text { Doubling time }}{\text { Mean } \pm \text { SD (h) }}$} & \multicolumn{3}{|c|}{ Cell cycle } \\
\hline & & G0/G1 (\%) & $\mathrm{S}(\%)$ & $\mathrm{G} 2 / \mathrm{M}(\%)$ \\
\hline TPC-1 WT & $25.00 \pm 4.61$ & $80.86 \pm 4.15$ & $8.20 \pm 2.95$ & $10.82 \pm 1.60$ \\
\hline TPC-1 + pcDNA3 & NT & $80.2 \pm 13.15$ & $5.45 \pm 1.48$ & $13.90 \pm 13.44$ \\
\hline TPC-1 + pcDNA TTF-1 & $43.12 \pm 5.76^{\mathrm{c}}$ & $93.70 \pm 2.63^{\mathrm{c}}$ & $3.34 \pm 2.28^{\mathrm{a}}$ & $2.30 \pm 0.57^{\mathrm{c}}$ \\
\hline TPC-1 + pcDNA PAX-8 & $25.23 \pm 2.87$ & $85.02 \pm 4.62$ & $6.32 \pm 3.30$ & $8.48 \pm 1.77$ \\
\hline BHP 10-3 WT & $47.12 \pm 5.95$ & $74.63 \pm 3.33$ & $17.10 \pm 1.67$ & $12.65 \pm 3.31$ \\
\hline BHP 10-3 + pcDNA3 & NT & $77.95 \pm 0.78$ & $12.00 \pm 1.93$ & $15.65 \pm 1.06$ \\
\hline BHP 10-3 + pcDNA TTF-1 & $57.75 \pm 5.57^{\mathrm{b}}$ & $77.93 \pm 2.74$ & $11.00 \pm 1.41^{\mathrm{b}}$ & $11.05 \pm 2.20$ \\
\hline BHP 10-3 + pcDNA PAX-8 & $33.36 \pm 3.68^{c}$ & $58.30 \pm 13.23$ & $18.9 \pm 7.3$ & $18.98 \pm 6.92$ \\
\hline ARO WT & $28.73 \pm 2.14$ & $54.00 \pm 2.26$ & $32.90 \pm 0.28$ & $14.20 \pm 1.41$ \\
\hline ARO + pcDNA3 & NT & $59.25 \pm 0.49$ & $29.30 \pm 1.41$ & $11.05 \pm 2.05$ \\
\hline ARO + pcDNA TTF-1 & $47.13 \pm 3.24^{\mathrm{c}}$ & $61.70 \pm 0.42^{\mathrm{a}}$ & $23.55 \pm 2.76^{\mathrm{a}}$ & $15.75 \pm 1.91$ \\
\hline ARO + pcDNA PAX- 8 & $25.74 \pm 5.54$ & $56.55 \pm 2.90$ & $22.15 \pm 0.35^{\mathrm{c}}$ & $22.10 \pm 1.98^{\mathrm{a}}$ \\
\hline
\end{tabular}

Doubling time: WT cell lines and their corresponding stably transfected clones were incubated in IncuCyte ${ }^{\mathrm{TM}}$. The time lapse cell confluence was obtained for each cell type and their doubling time was calculated. NT, non tested for empty vector. Cell cycle: cells were incubated with propidium iodide (PI) after permeabilization and the repartition of cells within different phases of cell cycle was analysed by flow cytometry (FACS). All results are expressed as mean $\pm \mathrm{SD}$, stars indicate the degree of significance observed between WT and their corresponding clones. ${ }^{*} \mathrm{P}<0.05,{ }^{* *} \mathrm{P}<0.01,{ }^{* * *} \mathrm{P}<0.001$.
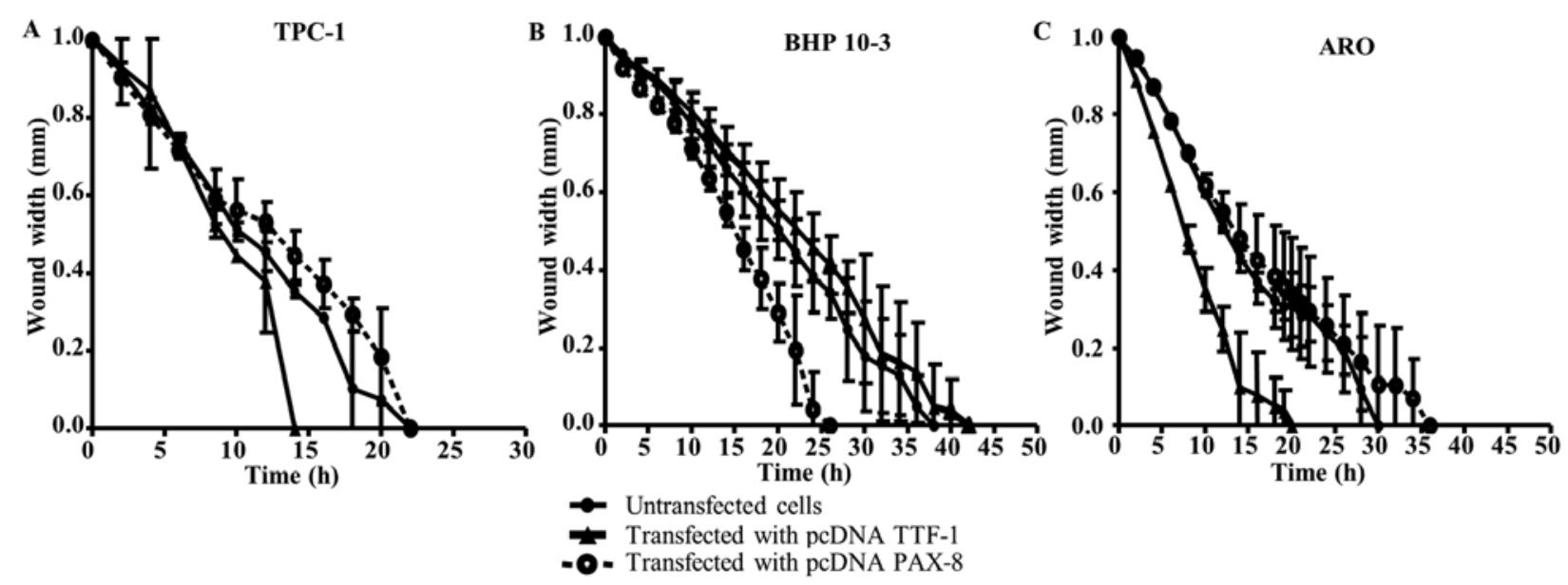

Figure 3. Migration ability of TPC-1, BHP 10-3 and ARO WT cell lines and their corresponding TTF- 1 and PAX-8 clones. The cell motility was determined by the IncuCyte ${ }^{\mathrm{TM}}$. Results are presented as relative wound width in function of time of WT cell lines and their respective clones stably transfected with pcDNA TTF-1 or pcDNA PAX-8. Migration ability of WT cells were compared to their corresponding clones. (A) TPC-1, (B) BHP 10-3 and (C) ARO. Bars represent mean \pm SD of two independent experiments.

and ARO derived clones but significantly increased the growth of BHP 10-3 clone; this might be due to high basal expression of PAX-8 in BHP 10-3 WT cells compared to TPC-1 and ARO cells (Fig. 1B and C). Moreover, it should also be noted that the growth characteristics of each WT cell line is different, thus, making it difficult to compare their growth rate (TPC-1 and BHP 10-3 spread along the surface of the support while ARO grows in clusters).

These results were further supported by cell cycle studies, wherein we observed that $T T F-1$ induction triggered an increase in cell percentage at $\mathrm{G} 0 / \mathrm{G} 1$ phase, up to significant level for TPC-1 and ARO clones (Table I). Concerning the empty vector, the results of cell cycle studies did not show any difference between WT cells and the corresponding cell clones transfected with pcDNA3 alone (Table I).

These results suggest that in the tested cell lines, only TTF- 1 could have anti-proliferative effects by delaying cell growth and halting cell cycle in G0/G1 phase.

A high basal state expression of PAX-8 influences the migration ability. Wild-type cell lines and their corresponding clones were assessed for their migration ability. We observed that 


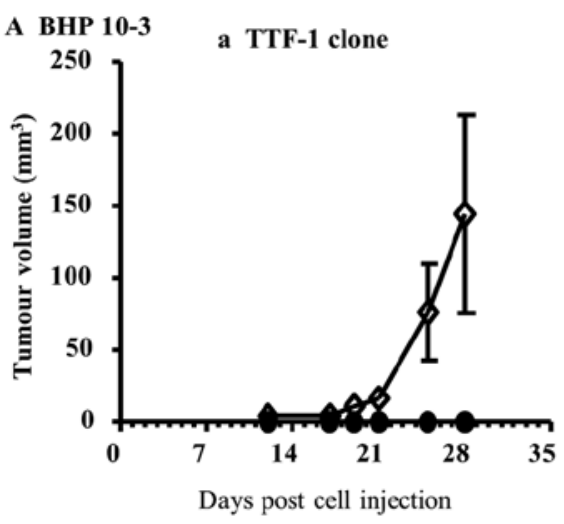

B ARO

a TTF-1 clone

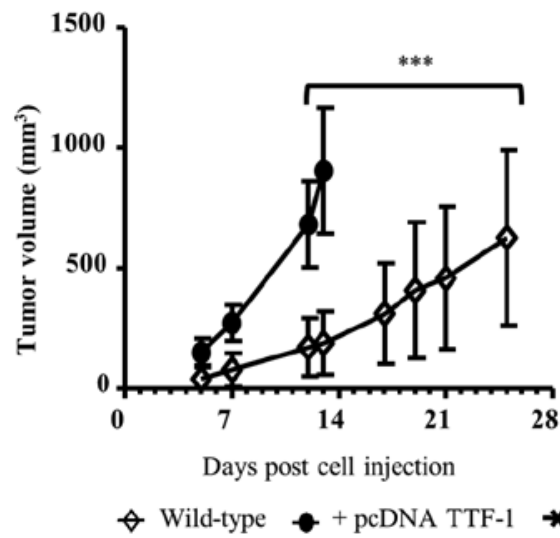

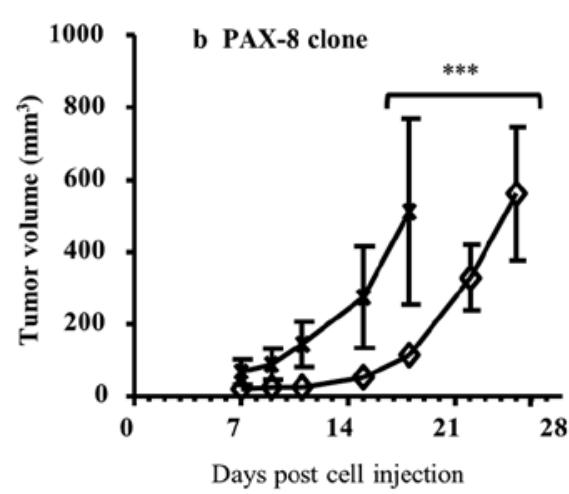

Days post cell injection

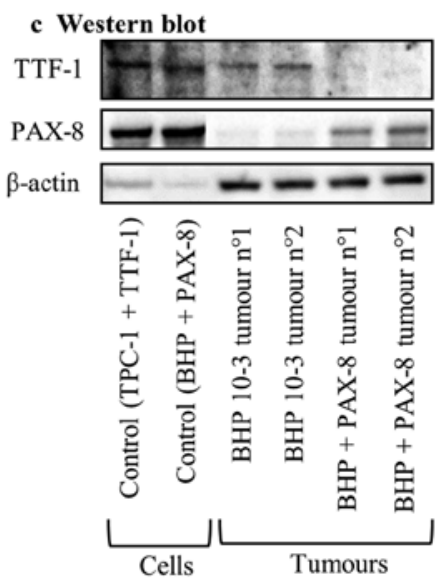

c Western blot b PAX-8 clone

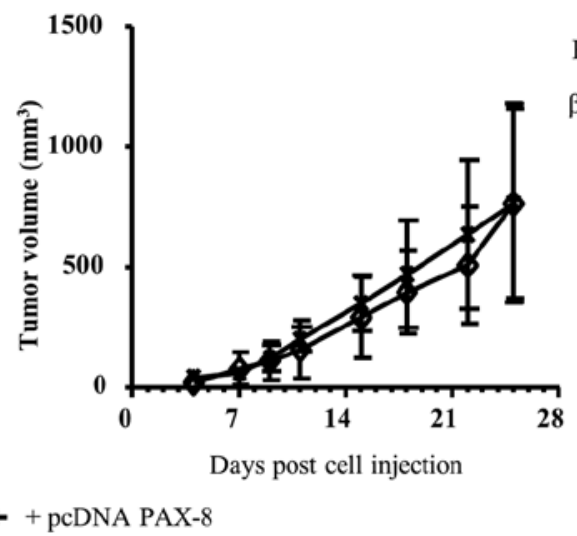

TTF-1

PAX-8

$\beta$-actin

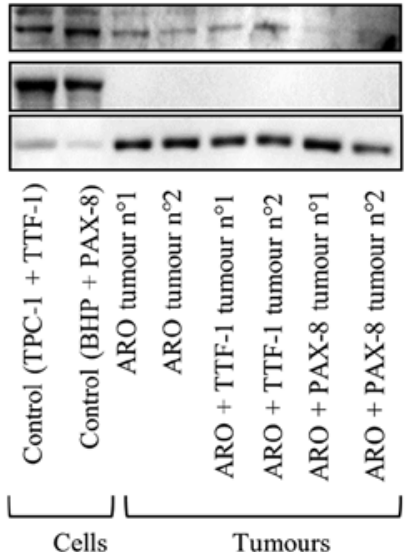

Figure 4. Tumorigenicity of BHP 10-3 and ARO and their corresponding stably transfected clones. Cell lines were tested for their tumorigenic ability in nude mice. Results are presented as tumour volume in function of time. Nude mice (n=5/group) were injected with BHP 10-3 cells (A) or with ARO cells (B). The corresponding clones transfected with pcDNA TTF-1 (A-a and B-a) or with pcDNA PAX-8 (A-b and B-b) were also xenografted. Tumour growth was followed during the course of the experiment until the tumour size reached $1 \mathrm{~cm}^{3}$. Mice were sacrificed and tumours were collected for western blot analysis using TTF-1 or PAX-8 antibodies (A-c and B-c). Positive controls were the clones derived from TPC-1 or BHP 10-3 cell lines maintained in culture medium. 'no. 1' and 'no. 2' represent the tumours collected from two different mice. $\beta$-actin was monitored as loading control. BHP, BHP 10-3; TTF-1, pcDNA TTF-1; PAX-8, pcDNA PAX-8.

TTF-1 transfection leads to increased cell migration in clones derived from TPC-1 and ARO WT cell lines (respectively for clones vs. WT: 14 vs. $22 \mathrm{~h}$ for TPC-1 and 14 vs. $30 \mathrm{~h}$ for ARO; Fig. 3A and C, respectively); no effects were observed for BHP $10^{-3}$ cells. While in this latter cell line, PAX- 8 transfection enhanced the migration of its corresponding clone (respectively for clone vs. WT: 24 vs. 35 h; Fig. 3B). However, PAX-8 transfection did not affect the migration of TPC-1 and ARO cells. Herein, each transcription factor also seems to have an impact on the migration behavior that appeared to be more influenced when a high PAX-8 basal state level was detected.

TTF-1 expression mainly influences tumorigenicity. According to our previous results, we postulated that the induction of $T T F-1$ or $P A X-8$ could influence the tumorigenic potential. Concerning TPC-1 cells, known to be non-tumorigenic in nude mice (40), the enhancement in the expression of both transcription factors did not result in tumour formation in NSG mice, known to be more immuno-depressed than nude mice, injected with TPC-1 WT or with TPC-1 + pcDNA TTF-1 or TPC-1 + pcDNA PAX-8 clones (data not shown).
Regarding BHP 10-3 cell line, its injection in nude mice resulted in tumour development. This observation is in accordance with previous results showing that BHP 10-3 cells are tumorigenic in immuno-depressed mice (41). Notably, when BHP 10-3 + pcDNA TTF-1 clone highly expressing TTF-1 was injected in nude mice, no tumours developed (Fig. 4A-a). Contrastingly, the inoculation of BHP 10-3 + pcDNA PAX-8 clone in nude mice increased tumour growth (Fig. 4A-b). These results were further confirmed by western blot analysis. Tumours collected at the end of the experiments and analyzed for TTF-1 and of PAX-8 protein contents showed an increase in PAX-8 levels in tumours derived from BHP 10-3 + pcDNA PAX-8 clone compared to BHP 10-3 WT tumours. Whereas, the TTF-1 protein contents were less expressed in the same samples (Fig. 4A-c).

In ARO cell line, also known to be tumorigenic (40), TTF-1 induction (ARO + pcDNA TTF-1) increased tumour growth (Fig. 4B-a), whereas $P A X-8$ upregulation (ARO + pcDNA PAX-8) did not influence tumorigenicity (Fig. 4B-b). Herein, western blot analysis showed that TTF-1 protein pattern seems to be slightly increased in the ARO + pcDNA TTF-1 derived 
Table II. Effects of pharmacological molecules on expression of TTF-1 and PAX-8 in TPC-1, BHP10-3 and ARO thyroid cell lines.

\begin{tabular}{|c|c|c|c|c|c|c|}
\hline & \multicolumn{2}{|c|}{ TPC-1 } & \multicolumn{2}{|c|}{ BHP 10-3 } & \multicolumn{2}{|c|}{ ARO } \\
\hline & TTF-1 & PAX-8 & TTF-1 & PAX-8 & TTF-1 & PAX-8 \\
\hline $\mathrm{EtOH} 1 \%$ & $1.00 \pm 0.04$ & $1.00 \pm 0.06$ & $1.00 \pm 0.08$ & $1.00 \pm 0.07$ & $1.00 \pm 0.04$ & $1.00 \pm 0.10$ \\
\hline TSA $0.3 \mu \mathrm{M}$ & $1.12 \pm 0.54$ & $1.56 \pm 0.28^{a}$ & $0.95 \pm 0.16$ & $0.71 \pm 0.10^{\mathrm{a}}$ & $2.80 \pm 0.37^{b}$ & $1.09 \pm 0.10$ \\
\hline TSA $1 \mu \mathrm{M}$ & $2.66 \pm 0.46^{\mathrm{a}}$ & $5.98 \pm 1.57^{b}$ & $4.13 \pm 1.96^{\mathrm{a}}$ & $1.21 \pm 0.08^{\mathrm{a}}$ & $17.65 \pm 0.46^{\mathrm{c}}$ & $1.16 \pm 0.02$ \\
\hline VPA $3 \mathrm{mM}$ & $5.20 \pm 1.47^{\mathrm{a}}$ & $1.35 \pm 0.20$ & $1.99 \pm 0.22^{b}$ & $1.55 \pm 0.05^{\mathrm{a}}$ & $2.70 \pm 0.53^{\mathrm{a}}$ & $5.23 \pm 1.24^{\mathrm{b}}$ \\
\hline 5'AZA $0.5 \mu \mathrm{M}$ & $0.30 \pm 0.11^{\mathrm{b}}$ & $0.31 \pm 0.13^{c}$ & $0.40 \pm 0.10^{\mathrm{b}}$ & $0.56 \pm 0.17^{\mathrm{a}}$ & $14.92 \pm 1.37^{\mathrm{b}}$ & $2.56 \pm 0.60^{\mathrm{a}}$ \\
\hline 5'AZA $1.0 \mu \mathrm{M}$ & $0.27 \pm 0.09^{b}$ & $0.30 \pm 0.09^{c}$ & $0.36 \pm 0.09^{a}$ & $0.72 \pm 0.32$ & $15.25 \pm 0.56^{\mathrm{b}}$ & $3.27 \pm 0.08^{\mathrm{c}}$ \\
\hline $\mathrm{LiCl} 10$ mM & $3.54 \pm 1.11^{\mathrm{a}}$ & $2.37 \pm 1.32^{\mathrm{a}}$ & $0.65 \pm 0.18$ & $0.97 \pm 0.08$ & $0.23 \pm 0.05^{\mathrm{b}}$ & $0.76 \pm 0.15$ \\
\hline BOR $100 \mathrm{nM}$ & $4.37 \pm 1.39^{\mathrm{a}}$ & $1.82 \pm 0.66$ & $1.81 \pm 0.55^{\mathrm{a}}$ & $0.91 \pm 0.09$ & $0.46 \pm 0.13^{b}$ & $0.51 \pm 0.09^{\mathrm{a}}$ \\
\hline
\end{tabular}

Variations in expression of TTF- 1 and PAX-8 were observed in TPC-1, BHP 10-3 and ARO cells after 48-h treatment by trichostatin A (TSA), valproic acid (VPA), 5'-azacytidine (5'-AZA), lithium chloride $(\mathrm{LiCl})$ and bortezomib (BOR). The control represents the cells treated with the vehicle $(\mathrm{EtOH}=1 \%)$. TTF-1 and $P A X-8 \mathrm{mRNA}$ expressions were quantified by real-time qPCR and normalized with GAPDH mRNA level. Results of three independent experiments are reported as mean \pm SD. Mann-Whitney statistical test was used to compare the difference between treated and untreated cells. Stars represent significant differences; ${ }^{*} \mathrm{P}<0.05,{ }^{* *} \mathrm{P}<0.01,{ }^{* * * *} \mathrm{P}<0.001$.

Table III. Effects of epigenetic modulators on apoptosis of TPC-1, BHP 10-3 and ARO cell lines.

\begin{tabular}{|c|c|c|c|c|c|c|}
\hline & \multicolumn{2}{|c|}{ TPC-1 } & \multicolumn{2}{|c|}{ BHP 10-3 } & \multicolumn{2}{|c|}{$\mathrm{ARO}$} \\
\hline & EA & LA & EA & LA & EA & LA \\
\hline $\mathrm{EtOH} 1 \%$ & $1.00 \pm 0.03$ & $1.00 \pm 0.03$ & $1.00 \pm 0.02$ & $1.00 \pm 0.02$ & $1.00 \pm 0.03$ & $1.00 \pm 0.02$ \\
\hline TSA $0.3 \mu \mathrm{M}$ & $1.42 \pm 0.02^{\mathrm{c}}$ & $1.50 \pm 0.02^{\mathrm{a}}$ & $1.18 \pm 0.02^{\mathrm{c}}$ & $1.00 \pm 0.02$ & $2.02 \pm 0.02^{\mathrm{b}}$ & $1.10 \pm 0.03^{\mathrm{c}}$ \\
\hline $\mathrm{TSA} 1 \mu \mathrm{M}$ & $1.84 \pm 0.01^{\mathrm{c}}$ & $1.51 \pm 0.01^{\mathrm{b}}$ & $1.32 \pm 0.01^{\mathrm{c}}$ & $0.66 \pm 0.01^{\mathrm{c}}$ & $2.21 \pm 0.15^{\mathrm{b}}$ & $2.33 \pm 0.08^{\mathrm{c}}$ \\
\hline VPA 3 mM & $1.10 \pm 0.01^{\mathrm{b}}$ & $5.00 \pm 0.01^{\mathrm{c}}$ & $1.10 \pm 0.01^{\mathrm{a}}$ & $1.00 \pm 0.01$ & $1.10 \pm 0.01^{\mathrm{b}}$ & $1.43 \pm 0.07^{\mathrm{b}}$ \\
\hline $5^{\prime}-\mathrm{AZA} 0.5 \mu \mathrm{M}$ & $1.48 \pm 0.01^{\mathrm{b}}$ & $4.00 \pm 0.01^{\mathrm{c}}$ & $0.88 \pm 0.02$ & $2.50 \pm 0.02^{\mathrm{b}}$ & $1.87 \pm 0.03^{\mathrm{c}}$ & $0.84 \pm 0.04$ \\
\hline 5'-AZA $1.0 \mu \mathrm{M}$ & $1.55 \pm 0.01^{\mathrm{b}}$ & $3.00 \pm 0.02^{\mathrm{c}}$ & $1.02 \pm 0.01$ & $2.50 \pm 0.02^{\mathrm{b}}$ & $1.53 \pm 0.06^{c}$ & $1.13 \pm 0.07$ \\
\hline $\mathrm{LiCl} 10 \mathrm{mM}$ & $1.40 \pm 0.05^{\mathrm{c}}$ & $4.00 \pm 0.05^{\mathrm{c}}$ & $0.89 \pm 0.05$ & $2.00 \pm 0.05^{\mathrm{b}}$ & $1.29 \pm 0.05^{\mathrm{b}}$ & $0.91 \pm 0.04$ \\
\hline BOR $100 \mathrm{nM}$ & $2.22 \pm 0.04^{\mathrm{c}}$ & $2.00 \pm 0.04^{\mathrm{b}}$ & $1.00 \pm 0.04$ & $3.70 \pm 0.04^{\mathrm{b}}$ & $2.22 \pm 0.20^{\mathrm{b}}$ & $2.04 \pm 0.05^{\mathrm{b}}$ \\
\hline
\end{tabular}

TPC-1, BHP 10-3 and ARO cells were treated for $48 \mathrm{~h}$ with trichostatine A (TSA), valproic acid (VPA), 5'-azacytidine (5'-AZA), lithium chloride $(\mathrm{LiCl})$ and bortezomib $(\mathrm{BOR})$. The cells treated with vehicle $(\mathrm{EtOH}=1 \%)$ were used as an internal control. Cells were labelled with Annexin-V (AV) and propidium iodide (PI). Early apoptosis $\left(\mathrm{EA} ; \mathrm{AV}^{+} \mathrm{PI}\right)$, late apoptosis $\left(\mathrm{LA} ; \mathrm{AV}^{+} \mathrm{PI}^{+}\right)$. Results are expressed as mean $\pm \mathrm{SD}$. Mann-Whitney statistical test was used to compare the difference between treated and untreated cells. Stars represent significant differences; ${ }^{*} \mathrm{P}<0.05,{ }^{* *} \mathrm{P}<0.01,{ }^{* * *} \mathrm{P}<0.001$.

clone. Concerning $P A X-8$, the protein was not expressed either in ARO derived clones (pcDNA TTF-1 and pcDNA PAX-8) or in the corresponding WT tumours (Fig. 4B-c).

Taken together, these results demonstrated that the basal state of $T T F-1$ or $P A X-8$ influences tumorigenicity. Moreover, $T T F-1$ seems to influence tumour development more than $P A X-8$ expression.

TTF-1 is more sensitive to epigenetic modulators than PAX-8. Then, the ability of some pharmacological agents to modulate expression of the TTF-1 and PAX-8 in TPC-1, BHP 10-3 and ARO cell lines was studied. It was found that $T T F-1$ expression seems to be more affected than $P A X-8$ by most of the molecules studied (Table II).
In TPC-1 cells, all molecules except 5'-AZA increased $T T F-1$ expression whereas, only $\mathrm{LiCl}$ and TSA significantly induced the $P A X-8$ level (Table II).

Regarding BHP 10-3 cells, all molecules enhanced TTF-1 expression except for GSK-3 $\beta$ inhibitor $(\mathrm{LiCl})$ and 5'-AZA which inhibited it. $P A X-8$ expression was slightly induced only by VPA and reduced by both TSA and 5'-AZA (Table II).

In ARO cell line, only epigenetic modulators (HDACi and demethylating agents) significantly increased $T T F-1$ expression, while $\mathrm{LiCl}$ and $\mathrm{BOR}$ lead to its inhibition (Table II). Concerning $P A X-8$, only VPA and 5'-AZA significantly increased its expression while BOR significantly decreased $P A X-8$ level (Table II). 
Epigenetic modulators provoke apoptosis. Flow cytometric analysis performed on TPC-1, BHP 10-3 and ARO cell lines showed that the used molecules could stimulate apoptosis (Table III). Regarding TPC-1 cell line, all the tested molecules induced early and late apoptosis (Table III). Notably, for BHP 10-3 cells, only HDACi were able to provoke early apoptosis while all the other molecules induced late apoptosis (Table III). Concerning ARO cell line, all the tested molecules induced early apoptosis however, only HDACi and BOR triggered late apoptosis (Table III).

\section{Discussion}

$T T F-1$ and $P A X-8$ are the major transcription factors involved in the development and differentiation of thyroid gland and play a key role in regulating the expressions of thyroid genes. We hypothesized that an enhancement of expression of TTF-1 and $P A X-8$ could affect both aggressiveness and tumorigenic properties. This hypothesis was evaluated in three models of thyroid carcinoma, two cell lines derived from PTC (TPC-1, BHP 10-3) and one from anaplastic carcinoma (ARO cell line).

In these models, we studied the basal state of TTF-1 and $P A X-8$ expression. Our results are in accordance with previous studies showing the presence of both transcription factors in TPC-1 and BHP 10-3 cells $(30,42)$. Concerning ARO anaplastic cell line, only TTF- 1 was detected, thus providing once more evidence of its thyroid origin $(43,44)$. Moreover, our results showed that the basal state of the expression of $T T F-1$ and $P A X-8$ is a major parameter that must always be taken into consideration and could explain the divergence of results among various studies concerning the role of these factors $(6,10,11,17)$. In fact, we found that the upregulation of either TTF-1 or PAX-8 could affect tumorigenic behavior independently of the histological origin of the cell lines used. We also confirmed previous observations showing that the overexpression of TTF- 1 induces $P A X-8$ expression (45-47).

The functional studies depicted the importance of TTF-1 in the regulation of cell cycle, migration and tumorigenicity. TTF-1 overexpression led to anti-proliferative effects reflected by an increase in doubling time and raised cell percentage in G0/G1 phase leading to a decrease in cell migration and tumorigenic potential. Contrastingly, this inspection was not confirmed in ARO cells, wherein the upregulation of TTF-1 led to an increase in cell migration and tumorigenicity. We hypothesized that the migratory and consequently the tumorigenic potential of enhanced $T T F-1$ level are dependent on its background expression within the cell lines. Thus, the 'TTF-1 paradox' is again highlighted $(10,48)$. In the same context, functional studies of $P A X-8$ depicted that its basal state plays a key role in proliferation and tumorigenicity which are enhanced when PAX-8 is highly expressed in tumor cells.

Taken together, our observations converge to the findings that the induction of TTF-1 and $P A X-8$ and their consequences on tumour growth depends on their basal states. Overexpression of one of these factors beyond a certain 'threshold' level could lead to pro-tumorigenic effects. Therefore, the modulation of these genes seems to be important to re-establish the differentiation balance.

To improve this hypothesis, we modulated the expression of TTF-1 and PAX-8 by several pharmacological agents. In the case of TTF-1, our results support the observations reported in the literature showing that $T T F-1$ is mainly regulated by epigenetic mechanisms such as methylation and acetylation but also by inhibitors of GSK-3 $\beta$ and of proteasome $(28,30)$. Whereas, $P A X-8$ generally appeared to be less sensitive to different treatments; suggesting that other molecular mechanisms might also be involved in its regulation. Interestingly, demethylating agent (5'-AZA) was capable of inducing $P A X-8$ only in ARO cell line, emphasizing that $P A X-8$ regulation in anaplastic thyroid tumours is different from PTC.

The evaluation of these molecules on apoptosis showed that all the used molecules triggered early and/or late apoptosis or in some cases both. It is further important to highlight the fact that, even though some agents did not modulate gene expression, they succeeded in triggering apoptosis. Indeed, these pharmacological agents have a large spectrum and a wide range of targets $(21,49,50)$. Epigenetic modulators such as HDACi or demethylating agents (TSA, VPA and 5'-AZA) used in our experiments are known to act directly on DNA conformation and therefore, on the regulation of several genes to induce inhibition of proliferation, cell cycle arrest, apoptosis and even senescence (49). In the same way, BOR or $\mathrm{LiCl}$ also act on several signaling pathways $(51,52)$.

Taken together, our results suggest that different pathways could be involved in regulation of $T T F-1$ and $P A X-8$. Therefore, the response to various treatments could be different according to the genetic background of the cell line studied. Nevertheless, we can speculate that an excessive induction of both transcription factors could lead to pro-tumorigenic effects e.g. treatment with 5'-AZA in anaplastic carcinomas could have opposite unintended effects. Indeed, 5'-AZA showed to increase, in vitro, iodine uptake and the expression of NIS (53) and has been tested in phase-I clinical trials. The positive effects of its use after clinical trials have not yet been published (https://clinicaltrials.gov/ct2/show/NCT00004062?t erm=azacytidine+thyroid\&rank=1).

In conclusion, the present study improved our understandings regarding the role of thyroid transcription factors in tumorigenesis. We showed that both genetic and pharmacological approaches are able to induce expression of TTF-1 and $P A X-8$. Thus, in future, it will be quite helpful to systematically take into account the basal state of these transcription factors while exploring tumour development. Moreover, it will also be important to consider TTF- $I$ and $P A X-8$ as part of a duo. These findings could open new therapeutic perspectives for the treatment of thyroid carcinomas.

\section{Acknowledgements}

We thank Professor Karim Benihoud and Dr Corinne Dupuy for their support and constructive discussions during the execution of the present study.

\section{References}

1. Civitareale D, Lonigro R, Sinclair AJ and Di Lauro R: A thyroidspecific nuclear protein essential for tissue-specific expression of the thyroglobulin promoter. EMBO J 8: 2537-2542, 1989.

2. Guazzi S, Price M, De Felice M, Damante G, Mattei MG and DiLauro R: Thyroid nuclear factor 1 (TTF-1) contains a homeodomain and displays a novel DNA binding specificity. EMBO J 9: 3631-3639, 1990. 
3. Ordóñez NG: Value of thyroid transcription factor-1 immunostaining in distinguishing small cell lung carcinomas from other small cell carcinomas. Am J Surg Pathol 24: 1217-1223, 2000.

4. Chen J, Wall NR, Kocher K, Duclos N, Fabbro D, Neuberg D, Griffin JD, Shi Y and Gilliland DG: Stable expression of small interfering RNA sensitizes TEL-PDGFbetaR to inhibition with imatinib or rapamycin. J Clin Invest 113: 1784-1791, 2004.

5. Ziad A, Ruchala M, Breborowicz J, Gembicki M, Sowinski J and Grzymislawski M: Immunoexpression of TTF-1 and Ki-67 in a coexistent anaplastic and follicular thyroid cancer with rare long-life surviving. Folia Histochem Cytobiol 46: 461-464, 2008.

6. Zhang P, Zuo H, Nakamura Y, Nakamura M, Wakasa T and Kakudo K: Immunohistochemical analysis of thyroid-specific transcription factors in thyroid tumors. Pathol Int 56: 240-245, 2006.

7. Ordóñez NG: Thyroid transcription factor-1 is a marker of lung and thyroid carcinomas. Adv Anat Pathol 7: 123-127, 2000.

8. Fenton CL, Patel A, Burch HB, Tuttle RM and Francis GL: Nuclear localization of thyroid transcription factor-1 correlates with serum thyrotropin activity and may be increased in differentiated thyroid carcinomas with aggressive clinical course. Ann Clin Lab Sci 31: 245-252, 2001.

9. Barletta JA, Perner S, Iafrate AJ, Yeap BY, Weir BA, Johnson LA, Johnson BE, Meyerson M, Rubin MA, Travis WD, et al: Clinical significance of TTF-1 protein expression and TTF-1 gene amplification in lung adenocarcinoma. J Cell Mol Med 13 (8B): 1977-1986, 2009.

10. Yamaguchi T, Hosono $\mathrm{Y}$, Yanagisawa $\mathrm{K}$ and Takahashi $\mathrm{T}$ : NKX2-1/TTF-1: An enigmatic oncogene that functions as a double-edged sword for cancer cell survival and progression. Cancer Cell 23: 718-723, 2013.

11. $\mathrm{Mu} \mathrm{D}$ : The complexity of thyroid transcription factor 1 with both pro- and anti-oncogenic activities. J Biol Chem 288: 24992-25000, 2013.

12. Hwang DH, Sholl LM, Rojas-Rudilla V, Hall DL, Shivdasani P, Garcia EP, MacConaill LE, Vivero M, Hornick JL, Kuo FC, et al: KRAS and NKX2-1 mutations in invasive mucinous adenocarcinoma of the lung. J Thorac Oncol 11: 496-503, 2016.

13. Takanashi Y, Tajima S, Hayakawa T, Neyatani H and Funai K: KRAS mutation-positive bronchial surface epithelium (BSE)type lung adenocarcinoma with strong expression of TTF-1: A case providing a further insight as for the role of TTF-1 in the oncogenesis. Int J Clin Exp Pathol 8: 15338-15343, 2015.

14. Hu Y, Hartmann A, Stoehr C, Zhang S, Wang M, Tacha D, Montironi R, Lopez-Beltran A and Cheng L: PAX8 is expressed in the majority of renal epithelial neoplasms: An immunohistochemical study of 223 cases using a mouse monoclonal antibody. J Clin Pathol 65: 254-256, 2012.

15. Laury AR, Perets R, Piao H, Krane JF, Barletta JA, French C, Chirieac LR, Lis R, Loda M, Hornick JL, et al: A comprehensive analysis of PAX8 expression in human epithelial tumors. Am J Surg Pathol 35: 816-826, 2011

16. Ordóñez NG: Value of PAX 8 immunostaining in tumor diagnosis: A review and update. Adv Anat Pathol 19: 140-151, 2012.

17. Nonaka D, Tang Y, Chiriboga L, Rivera M and Ghossein R: Diagnostic utility of thyroid transcription factors Pax8 and TTF-2 (FoxE1) in thyroid epithelial neoplasms. Mod Pathol 21: $192-200,2008$

18. Presta I, Arturi F, Ferretti E, Mattei T, Scarpelli D, Tosi E, Scipioni A, Celano M, Gulino A, Filetti S, et al: Recovery of NIS expression in thyroid cancer cells by overexpression of Pax8 gene. BMC Cancer 5: 80, 2005

19. Mu D, Huang R, Li S, Ma X, Lou C and Kuang A: Combining transfer of TTF-1 and Pax-8 gene: A potential strategy to promote radioiodine therapy of thyroid carcinoma. Cancer Gene Ther 19: 402-411, 2012.

20. Antonica F, Kasprzyk DF, Opitz R, Iacovino M, Liao XH, Dumitrescu AM, Refetoff S, Peremans K, Manto M, Kyba M, et al: Generation of functional thyroid from embryonic stem cells. Nature 491: 66-71, 2012.

21. Dokmanovic M, Clarke C and Marks PA: Histone deacetylase inhibitors: Overview and perspectives. Mol Cancer Res 5: 981-989, 2007

22. Slingerland M, Guchelaar HJ and Gelderblom H: Histone deacetylase inhibitors: An overview of the clinical studies in solid tumors. Anticancer Drugs 25: 140-149, 2014.
23. Fortunati N, Catalano MG, Arena K, Brignardello E, Piovesan A and Boccuzzi G: Valproic acid induces the expression of the $\mathrm{Na}^{+} / \mathrm{I}^{-}$symporter and iodine uptake in poorly differentiated thyroid cancer cells. J Clin Endocrinol Metab 89: 1006-1009, 2004.

24. Furuya F, Shimura H, Suzuki H, Taki K, Ohta K, Haraguchi K, Onaya T, Endo T and Kobayashi T: Histone deacetylase inhibitors restore radioiodide uptake and retention in poorly differentiated and anaplastic thyroid cancer cells by expression of the sodium/iodide symporter thyroperoxidase and thyroglobulin. Endocrinology 145: 2865-2875, 2004.

25. Pugliese M, Fortunati N, Germano A, Asioli S, Marano F, Palestini N, Frairia R, Boccuzzi G and Catalano MG: Histone deacetylase inhibition affects sodium iodide symporter expression and induces $131 \mathrm{I}$ cytotoxicity in anaplastic thyroid cancer cells. Thyroid 23: 838-846, 2013.

26. Puppin C, D'Aurizio F, D'Elia AV, Cesaratto L, Tell G, Russo D, Filetti S, Ferretti E, Tosi E, Mattei T, et al: Effects of histone acetylation on sodium iodide symporter promoter and expression of thyroid-specific transcription factors. Endocrinology 146: 3967-3974, 2005

27. Vivaldi A, Miasaki FY, Ciampi R, Agate L, Collecchi P, Capodanno A, Pinchera A and Elisei R: Re-differentiation of thyroid carcinoma cell lines treated with 5-Aza-2'-deoxycytidine and retinoic acid. Mol Cell Endocrinol 307: 142-148, 2009.

28. Kondo T, Nakazawa T, Ma D, Niu D, Mochizuki K, Kawasaki T, Nakamura N, Yamane T, Kobayashi M and Katoh R: Epigenetic silencing of TTF-1/NKX2-1 through DNA hypermethylation and histone $\mathrm{H} 3$ modulation in thyroid carcinomas. Lab Invest 89: 791-799, 2009.

29. Raouane M, Desmaele D, Gilbert-Sirieix M, Gueutin C, Zouhiri F, Bourgaux C, Lepeltier E, Gref R, Ben Salah R, Clayman G, et al: Synthesis, characterization, and in vivo delivery of siRNAsqualene nanoparticles targeting fusion oncogene in papillary thyroid carcinoma. J Med Chem 54: 4067-4076, 2011

30. Gilbert-Sirieix M, Makoukji J, Kimura S, Talbot M, Caillou B, Massaad C and Massaad-Massade L: Wnt $/ \beta$-catenin signaling pathway is a direct enhancer of thyroid transcription factor-1 in human papillary thyroid carcinoma cells. PLoS One 6: e22280, 2011.

31. Yamazaki CA, Padovani RP, Biscolla RP, Ikejiri ES, Marchetti RR, Castiglioni ML, Matsumura LK, Maciel RM and Furlanetto RP: Lithium as an adjuvant in the postoperative ablation of remnant tissue in low-risk thyroid carcinoma. Thyroid 22: 1002-1006, 2012.

32. Altmann A, Markert A, Askoxylakis V, Schöning T, Jesenofsky R, Eisenhut $\mathrm{M}$ and Haberkorn U: Antitumor effects of proteasome inhibition in anaplastic thyroid carcinoma. J Nucl Med 53: 1764-1771, 2012.

33. Oliva J,Dedes J,Li J,French SW and Bardag-Gorce F: Epigenetics of proteasome inhibition in the liver of rats fed ethanol chronically. World J Gastroenterol 15: 705-712, 2009.

34. Pohlenz J, Dumitrescu A, Zundel D, Martiné U, Schönberger W, Koo E, Weiss RE, Cohen RN, Kimura S and Refetoff S: Partial deficiency of thyroid transcription factor 1 produces predominantly neurological defects in humans and mice. J Clin Invest 109: 469-473, 2002.

35. Vilain C, Rydlewski C, Duprez L, Heinrichs C, Abramowicz M, Malvaux P, Renneboog B, Parma J, Costagliola S and Vassart G: Autosomal dominant transmission of congenital thyroid hypoplasia due to loss-of-function mutation of PAX8. J Clin Endocrinol Metab 86: 234-238, 2001.

36. Ali HM, Maksimenko A, Urbinati G, Chapuis H, Raouane M, Desmaële D, Yasuhiro H, Harashima H, Couvreur P and Massaad-Massade L: Effects of silencing the RET/PTC1 oncogene in papillary thyroid carcinoma by siRNA-squalene nanoparticles with and without fusogenic companion GALAcholesterol. Thyroid 24: 327-338, 2014.

37. Livak KJ and Schmittgen TD: Analysis of relative gene expression data using real-time quantitative PCR and the 2(-Delta Delta C(T)) method. Methods 25: 402-408, 2001.

38. Urbinati G, Ali HM, Rousseau Q, Chapuis H, Desmaële D, Couvreur P and Massaad-Massade L: Antineoplastic effects of siRNA against TMPRSS2-ERG junction oncogene in prostate cancer. PLoS One 10: e0125277, 2015

39. Ali HM, Urbinati G, Chapuis H, Desmaele D, Bertrand JR, Couvreur P and Massaad-Massade L: Effects of siRNA on RET/ PTC3 junction oncogene in papillary thyroid carcinoma: From molecular and cellular studies to preclinical investigations. PLoS One 9: e95964, 2014. 
40. Ouyang B, Knauf JA, Smith EP, Zhang L, Ramsey T, Yusuff N, Batt D and Fagin JA: Inhibitors of Raf kinase activity block growth of thyroid cancer cells with RET/PTC or BRAF mutations in vitro and in vivo. Clin Cancer Res 12: 1785-1793, 2006.

41. Ahn SH, Henderson Y, Kang Y, Chattopadhyay C, Holton P, Wang M, Briggs K and Clayman GL: An orthotopic model of papillary thyroid carcinoma in athymic nude mice. Arch Otolaryngol Head Neck Surg 134: 190-197, 2008.

42. van Staveren WC, Solís DW, Delys L, Duprez L, Andry G, Franc B, Thomas G, Libert F, Dumont JE, Detours V, et al: Human thyroid tumor cell lines derived from different tumor types present a common dedifferentiated phenotype. Cancer Res 67: 8113-8120, 2007.

43. Chen ST, Shieh HY, Lin JD, Chang KS and Lin KH: Overexpression of thyroid hormone receptor betal is associated with thyrotropin receptor gene expression and proliferation in a human thyroid carcinoma cell line. J Endocrinol 165: 379-389, 2000.

44. Zito G, Richiusa P, Bommarito A, Carissimi E, Russo L, Coppola A, Zerilli M, Rodolico V, Criscimanna A, Amato M, et al: In vitro identification and characterization of CD133(pos) cancer stem-like cells in anaplastic thyroid carcinoma cell lines. PLoS One 3: e3544, 2008.

45. Christophe-Hobertus C, Lefort A, Libert F and Christophe D: Functional inactivation of thyroid transcription factor-1 in $\mathrm{PCCl} 3$ thyroid cells. Mol Cell Endocrinol 358: 36-45, 2012.
46. Miccadei S, De Leo R, Zammarchi E, Natali PG and Civitareale D: The synergistic activity of thyroid transcription factor 1 and Pax 8 relies on the promoter/enhancer interplay. Mol Endocrinol 16: 837-846, 2002.

47. Nitsch R, Di Dato V, di Gennaro A, de Cristofaro T, Abbondante S, De Felice M, Zannini M and Di Lauro R: Comparative genomics reveals a functional thyroid-specific element in the far upstream region of the PAX8 gene. BMC Genomics 11: 306, 2010.

48. Gilbert-Sirieix M and Massaad-Massade L: TTF-1: Neither angel nor demon. Med Sci (Paris) 27: 183-186, 2011 (In French).

49. Giannini G, Cabri W, Fattorusso C and Rodriquez M: Histone deacetylase inhibitors in the treatment of cancer: Overview and perspectives. Future Med Chem 4: 1439-1460, 2012.

50. Li KK, Li F, Li QS, Yang K and Jin B: DNA methylation as a target of epigenetic therapeutics in cancer. Anticancer Agents Med Chem 13: 242-247, 2013.

51. MacDonald BT, Tamai K and He X: Wnt/beta-catenin signaling: Components, mechanisms, and diseases. Dev Cell 17: 9-26, 2009.

52. Almond JB and Cohen GM: The proteasome: A novel target for cancer chemotherapy. Leukemia 16: 433-443, 2002.

53. Provenzano MJ, Fitzgerald MP, Krager K and Domann FE: Increased iodine uptake in thyroid carcinoma after treatment with sodium butyrate. Otolaryngol Head Neck Surg 137: 722-728, 2007. 